\title{
Lack of Induced Systemic Resistance in Peanut to Late Leaf Spot Disease by Plant Growth-Promoting Rhizobacteria and Chemical Elicitors
}

\author{
Shouan Zhang and M. S. Reddy, Department of Entomology and Plant Pathology, Alabama Agricultural Experi- \\ ment Station, Auburn University, Auburn, AL 36849; Nancy Kokalis-Burelle, USDA-ARS, U.S. Horticultural Re- \\ search Laboratory, Fort Pierce, FL 34945; Larry W. Wells and Stevan P. Nightengale, Alabama Agricultural Ex- \\ periment Station, Auburn University; and Joseph W. Kloepper, Department of Entomology and Plant Pathology, \\ Alabama Agricultural Experiment Station, Auburn University
}

\begin{abstract}
Zhang, S., Reddy, M. S., Kokalis-Burelle, N., Wells, L. W., Nightengale, S. P., and Kloepper, J. W. 2001. Lack of induced systemic resistance in peanut to late leaf spot disease by plant growth-promoting rhizobacteria and chemical elicitors. Plant Dis. 85:879-884.

A disease assay was optimized for late leaf spot disease of peanut using Cercosporidium personatum in the greenhouse, and this assay was used in attempts to elicit induced systemic resistance using strains of plant growth-promoting rhizobacteria (PGPR) and chemical elicitors. Nineteen strains of spore-forming bacilli PGPR, including strains of Paenibacillus macerans, Brevibacillus brevis, Bacillus laterosporus, B. subtilis, B. pumilus, B. amyloliquefaciens, B. sphaericus, B. cereus, and B. pasteurii, which previously elicited systemic disease control activity on other crops, were evaluated in greenhouse assays. Seven PGPR strains elicited significant disease reduction in a single experiment; however, none repeated significant protection achieved in the greenhouse assay, while significant protection consistently occurred with the fungicide chlorothalonil (Bravo). In other greenhouse trials, neither stem injections of C. personatum nor foliar sprays of chemicals, including salicylic acid, sodium salicylate, isonicotinic acid, or benzo[1,2,3]thiadiazole-7-carbothioc acid S-methyl ester (Actigard), which elicit systemic acquired resistance on other crops, elicited significant disease protection. In contrast, foliar sprays with DL- $\beta$-amino-n-butyric acid (BABA), which is an elicitor of localized acquired resistance, resulted in significantly less late leaf spot disease in one of two tests. Combination treatments of four PGPR strains with BABA in the greenhouse did not significantly protect peanut from late leaf spot. Field trials conducted over two growing seasons indicated that none of the 19 PGPR strains, applied as seed treatments at two concentrations, significantly reduced late leaf spot disease. The same chemical elicitors tested in the greenhouse, including BABA, did not elicit significant disease protection. Some combinations of four PGPR and BABA significantly reduced the disease at one but not at two sample times. Collectively, these results suggest that late leaf spot resistance in peanut is not systemically inducible in the same manner as is resistance to diseases in other crops by PGPR and chemical inducers.
\end{abstract}

Additional keywords: biological control

Early and late leaf spot diseases, caused by Cercospora arachidicola $\mathrm{S}$. Hori and Cercosporidium personatum (Berk. \& M. A. Curtis) Deighton, respectively, are the most widespread foliar diseases of peanut (Arachis hypogaea L.) (26), accounting for pod yield losses of up to $50 \%$ in severe epidemics (9). Management strategies for leaf spot epidemics rely on reducing initial inocula via crop rotation or on reducing the rate of disease spread via resistant cultivars and fungicide applications. Crop rotation out of peanut for 2 to 3 years is recommended, because this may delay the development of a leaf spot epidemic by 2 to 3

Corresponding author: J. W. Kloepper

E-mail: jkloeppe@acesag.auburn.edu

Accepted for publication 18 April 2001.

Publication no. D-2001-0618-02R

(C) 2001 The American Phytopathological Society weeks (11). However, because of the potential for a rapid rate of increase of leaf spot diseases, crop rotation alone is insufficient for control. A few high-yielding cultivars with moderate resistance to early or late leaf spots have been developed (8), but this resistance is not complete (25). Currently, management of peanut leaf spot diseases in the United States relies principally on foliar applications of fungicides (26). Benomyl, chlorothalonil, copper hydroxide, mancozeb, propiconazole, and tebuconazole are examples of fungicides that have been used or are being used for management of leaf spot diseases. Unfortunately, application of fungicides may result in undesirable effects. The use of either chlorothalonil or captafol for control of foliar diseases may increase the severity of Sclerotinia blight, caused by Sclerotinia minor (21). A consistently higher level of southern blight, caused by Sclerotium rolfsii, was observed in plots sprayed with benomyl than in unsprayed plots (2). Foliar sprays of either fentin hydroxide or copper ammonium carbonate suppressed populations of the two-spotted spider mite (3), whereas foliar sprays of diniconazole contribute to the increased populations (12). More importantly, some fungicides may increase the risk that resistant populations of leaf spot pathogens will develop. Benomyl-resistant strains of Cercospora arachidicola and Cercosporidium personatum developed in the southeastern United States within 3 years of the first use of benomyl $(4,14)$.

A potential alternative or complementary approach for managing peanut leaf spot diseases may be biological control. Although there have been no reported successes in using introduced biocontrol agents for control of peanut leaf spots, Kokalis-Burelle et al. (10) demonstrated that foliar sprays of chitin resulted in reduced leaf spot damage, presumably due to enhanced populations of indigenous antagonists.

Another potential disease management strategy would be to use the concepts of systemic acquired resistance (SAR) or induced systemic resistance (ISR) to activate host defense. The first chemical inducing agent was recently developed by Novartis Crop Protection (27). This compound, benzo[1,2,3]thiadiazole-7-carbothioc acid S-methyl ester, has the trade name Actigard in the United States. Foliar sprays of Actigard induce accumulation of pathogenesis-related proteins and lead to reduced incidence of several diseases on many crops, including cereals, rice, potato, tomato, miscellaneous vegetables, pome fruit, mango, citrus, grape, banana, peppers, and tobacco (27). Although Actigard was evaluated on peanut during the product development work, it did not consistently lead to systemic disease protection against peanut leaf spots (A. Tally, personal communication).

An alternative to using chemical inducers to activate SAR is the use of plantassociated microorganisms as inducers. Some strains of plant growth-promoting rhizobacteria (PGPR) elicit systemic disease protection, which has been termed ISR (28). Work over the past decade at Auburn University has identified several PGPR strains which, upon seed treatment, elicit ISR on cucumber, tomato, and to- 
bacco, causing reductions in severity of several foliar and systemic diseases under greenhouse and field conditions $(15,16$, 19,22-24,30-34). The objective of this research was to determine if late leaf spot of peanut could be managed by ISR elicited by PGPR, by SAR elicited by chemicals, or by combinations of PGPR and chemical elicitors.

\section{MATERIALS AND METHODS}

Bacterial and fungal cultures. Nine(Table 1) were selected for greenhouse tests and field trials; the strains had previously shown induced systemic protection in cucumber, tomato, or tobacco $(15,16$, 19,22-24,30-34). PGPR strains were stored in tryptic soy broth (TSB) amended with $20 \%$ glycerol at $-80^{\circ} \mathrm{C}$ prior to use. Bacterial cell suspensions were prepared by first streaking PGPR strains from ultracold storage onto tryptic soy agar (TSA) and incubating at $28^{\circ} \mathrm{C}$ for $24 \mathrm{~h}$ to check for purity, then transferring single colonies to spore preparation medium $(0.5 \%$ yeast extract, $0.5 \%$ peptone, $2 \%$ soluble starch, and $1.8 \%$ agar, $\mathrm{pH} 6.9$ ) for 7 to 10 days to yield nearly $100 \%$ sporulation. Spores were washed off plates by 10 to $15 \mathrm{ml}$ of sterilized distilled water. The spore suspenmined by microscopy, with sterilized distilled water for experimental use.

For use in greenhouse bioassays, the pathogen $C$. personatum was isolated from leaves of peanut cv. Florunner with typical disease symptoms collected in a field near Tifton, GA. The pathogen was stored and cultured on V8 juice agar $(7,17)$ amended with $1 \%$ yeast extract (V8A). After incubateen strains of spore-forming bacilli PGPR sions were adjusted to $10^{8} / \mathrm{ml}$, as deter-

tion for 3 weeks at $25^{\circ} \mathrm{C}, 15$ of $20 \mathrm{ml}$ of sterilized distilled water was added per V8A plate, and the fungus was gently removed from the plates $1 \mathrm{~h}$ later. The resulting fungal suspension $(1 \mathrm{ml})$ was evenly spread on a fresh V8A plate using a $200-\mu \mathrm{l}$ pipette with a large orifice tip. Inoculated plates were wrapped with Parafilm and incubated at $25^{\circ} \mathrm{C}$ with a 12 -h light and 12 $\mathrm{h}$ dark regime. Four weeks later, fungal cultures were scraped from the plates with sterilized water, stirred with a magnetic bar for $1 \mathrm{~h}$, then filtered with two layers of cheesecloth, and the inoculum density was adjusted to $10^{5}$ to $10^{6}$ mycelial fragments per milliliter using a hemocytometer under a light microscopy.

Optimization of peanut late leaf spot disease assay in the greenhouse. Peanut (cv. Florunner) seeds were mixed with Vitavax PC (Gustafson Inc., Dallas, TX) in a plastic bag at the rate of $1.13 \mathrm{~g}$ of Vitavax PC per $450 \mathrm{~g}$ of peanut seeds and shaken until even coverage was achieved. Peanut plants were grown in Pro-mix (Premier Peat Ld., Rivière-du-Loup Loup, Québec, Canada) in plastic pots (10 by 10 $\mathrm{cm}^{2}$ ) in the greenhouse at 25 to $28^{\circ} \mathrm{C}$ with $14 \mathrm{~h}$ of incandescent light per day. After emergence, the plants were fertilized with Peter's Peat Lite 20-10-20 once a week and watered every day.

An experiment was conducted in the greenhouse to determine the effect of plant age on occurrence and severity of late leaf spot disease. Treatments consisted of peanut plants at six different growth stages (3, $4,5,6,7$, and 8 weeks old). Plants were inoculated with $C$. personatum by spraying fungal suspensions $\left(1.6 \times 10^{5}\right.$ mycelial fragments/ml, with 2 drops of Tween 20)

Table 1. Summary of testing plant growth-promoting rhizobacteria (PGPR) applied as a root drench and foliar spray against Cercosporidium leaf spot of peanut in the greenhouse

\begin{tabular}{llcc}
\hline & \multicolumn{2}{c}{ Percent disease compared to a nontreated control } \\
\cline { 2 - 4 } Treatment & Identity of PGPR & Experiment 1 & Experiment 2 $^{\mathbf{a}}$ \\
\cline { 2 - 4 } 3PI-8 & Paenibacillus macerans & -16.8 & 7.5 \\
3PI-14 & P. macerans & -16.3 & -7.4 \\
1PC-11 & Brevibacillus brevis & 16.6 & 1.5 \\
1PL-2 & Bacillus laterosporus & 7.7 & 6.2 \\
1PN-19 & B. subtilis & $-30.0^{*}$ & 4.1 \\
INR-7 & B. pumilus & $-19.9^{*}$ & 3.1 \\
IN937a & B. amyloliquefaciens & 26.5 & 5.1 \\
IN937b & B. subtilis & 19.1 & -1.1 \\
T4 & B. pumilus & 7.2 & $-18.7^{*}$ \\
SE34 & B. pumilus & 2.2 & -11.4 \\
SE49 & B. pumilus & $-22.7^{*}$ & 1.8 \\
SE56 & B. sphaericus & -6.6 & -16.0 \\
SE76 & B. pumilus & -10.7 & -4.0 \\
C10 & B. cereus & 14.3 & -4.2 \\
C9 & B. pasteurii & 43.5 & -0.8 \\
C6 & B. cereus & $-25.7^{*}$ & 4.8 \\
C5 & B. cereus & $-19.4^{*}$ & 9.7 \\
C3 & B. cereus & 7.0 & -1.2 \\
C1 & B. cereus & -3.5 & $-18.8^{*}$ \\
Bravo 720 & .. & $-78.8^{*}$ & $-64.8^{*}$ \\
\hline
\end{tabular}

${ }^{a}$ Data shown are summarized from several experiments, and the appropriate nontreated control in each experiment was used to calculate the percentage of difference in disease, based upon the percentage of leaflets per plant with lesions. Each value is the mean of six replications and two plants per replication; * indicates significantly different from the nontreated control according to the least significant difference test at $P=0.05$. onto the top and bottom of leaves until runoff. Inoculated plants were placed in a plastic tent with a humidifier to generate $100 \%$ relative humidity on a bench in the greenhouse. The plastic tent was opened for $24 \mathrm{~h}$ every 3 days. Plants were watered and fertilized from the bottom of pots. The experiment was a randomized complete block with six replications per treatment and two plants per replication.

Another experiment was conducted to determine the effect of pathogen density on late leaf spot disease severity. Peanut plants, 4 to 6 weeks old, were inoculated with $C$. personatum at $10^{3}, 10^{4}$, and $10^{5}$ mycelial fragments $/ \mathrm{ml}$. The experiment was a randomized complete block with four treatments (three inoculum densities and one noninoculated control), six replications, and two plants per replication. Four weeks after pathogen challenge, late leaf spot disease was recorded by counting the number of lesions per plant or number of lesions per leaflet, and the percentage of leaflets per plant with any lesions. The experiment was repeated three times.

Screening of PGPR for potential to elicit systemic protection against late leaf spot in the greenhouse. PGPR were applied in one of three ways in the experiments. For seed treatment, $1.0 \mathrm{ml}$ of bacterial cell suspensions $\left(10^{8}\right.$ to $\left.10^{9} \mathrm{CFU} / \mathrm{ml}\right)$ was applied to each peanut seed in Pro-mix at the time of seeding, and seeds were then covered with $1.5 \mathrm{~cm}$ of Promix. For soil drench, $30 \mathrm{ml}$ of a $10^{8} \mathrm{CFU} / \mathrm{ml}$ bacterial suspension was poured into each pot at 2 to 3 weeks after planting. For foliar spray, bacterial suspensions at a concentration of $10^{8} \mathrm{CFU} / \mathrm{ml}$ were sprayed onto peanut leaves until run-off. One week later, plants were inoculated with $C$. personatum as described previously. Four weeks later, late leaf spot disease was recorded as the number of lesions per plant, number of leaflets per plant with any lesions, and percentage of leaflets per plant with any lesions.

An initial experiment was conducted with eight PGPR strains (SE34, SE49, T4, INR7, C1, C3, C5, and C6) and a nontreated control arranged as a randomized complete block with nine treatments and six replications per treatment. The bacteria were applied as seed treatments (as described above) at $10^{8}$ and $10^{9} \mathrm{CFU} / \mathrm{ml}$. The experiment was conducted twice.

Subsequent experiments used soil drench and spray application of PGPR to increase the possibility of elicitation of ISR by PGPR. A total of 19 PGPR strains (Table 1) were tested. All experiments were randomized complete blocks with five to eight PGPR strains, a nontreated control, and a fungicide control with chlorothalonil (Bravo 720) applied as a foliar spray at the time of application of PGPR. Each treatment was replicated six times with two plants per replication. Each PGPR strain was tested twice. Disease was rated as described above. 
Tests for elicitation of SAR by $C$. personatum and chemical inducers. An experiment was designed in the greenhouse to determine if SAR could be elicited in peanut by stem injection of $C$. personatum. Treatments consisted of six different intervals between the time of stem injection and challenge inoculation $(0,3,5,7,14$, and 21 days) and a nontreated control. The experiment was a randomized complete block with seven treatments, six replications per treatment, and two plants per replication. Stem injections were done using a $1-\mathrm{cm}^{3}$ syringe to inject $1.0 \mathrm{ml}$ of fungal suspension $\left(10^{5}\right.$ mycelial fragments $\left./ \mathrm{ml}\right)$ into stems $1 \mathrm{~cm}$ above the soil line. The needle was introduced tangentially to the stem and injections were made into the stem external to the xylem. Plants were challenged with $C$. personatum when they were 6 weeks old using the same methods as described previously.

An experiment was conducted in the greenhouse to determine if known chemical inducers of SAR in some crops could protect against late leaf spot. The chemical inducers tested were salicylic acid (SA), sodium salicylate (NaSA), DL- $\beta$-amino-nbutyric acid (BABA), isonicotinic acid (INA), and benzo [1,2,3] thiadiazole-7carbothioic acid S-methyl ester (Actigard). All inducers were applied as foliar sprays to run-off at 4 weeks after planting, and pathogen challenge was done 1 week later as described above. SA, NaSA, BABA, and INA were tested at $0.5,1.0,1.5$, and $2.0 \mathrm{mg} / \mathrm{ml}$, whereas Actigard was tested at $0.05,0.10,0.15$, and $0.20 \mathrm{mg} / \mathrm{ml}$. The experiment was a randomized complete block with six replications per treatment and two plants per replication. Disease was rated as the percentage of leaflets per plant with lesions 4 weeks after challenge. The experiment was conducted twice.

Another experiment was designed to determine if combinations of some PGPR strains and BABA could induce protection against late leaf spot. The tested PGPR strains were $\mathrm{C} 1, \mathrm{C} 3, \mathrm{C} 5$, and $\mathrm{T} 4$, which were applied as seed treatments at $10^{9}$ $\mathrm{CFU} / \mathrm{ml}$. BABA was applied as foliar sprays at 0.5 and $1.0 \mathrm{mg} / \mathrm{ml}$ at 4 weeks after planting, or as seed treatments at 2.5 and $3.0 \mathrm{mg} / \mathrm{ml}$ at the time of seeding. A nontreated control was included. The experiment was a randomized complete block with six replications and two plants per replication. The experiment was conducted twice.

Field trials. Field trials were designed to test the possible elicitation of induced resistance against late leaf spot of peanut by PGPR and chemical inducers over a 2year period. Trials were conducted at E. V. Smith Research Center near Shorter, AL and at the Wiregrass Substation near Headland, AL in 1997 and 1998. In 1997, eight field trials were conducted at E. V. Smith to assess 19 PGPR strains and the same five chemical inducers used in the green- house trials. Six of these eight trials tested greenhouse, and the other two trials tested the chemical inducers. Each PGPR strain was tested at $10^{7}$ and $10^{9} \mathrm{CFU} / \mathrm{ml}$ in the same trial. Similarly, each chemical was evaluated at two concentrations. The concentrations of chemical inducers tested were salicylic acid and sodium salicylate at 1.0 and $1.5 \mathrm{mg} / \mathrm{ml}$; BABA at 0.25 and 0.50 $\mathrm{mg} / \mathrm{ml}$; INA at 1.5 and $2.0 \mathrm{mg} / \mathrm{ml}$; and Actigard at 0.05 and $0.1 \mathrm{mg} / \mathrm{m}$. Six PGPR strains (INR-7, T4, SE34, SE49, C1, and C6, which previously elicited disease prothe same 19 PGPR strains tested in the

tections both in greenhouse and field conditions in some other crops) were tested in one trial at Headland in 1997. The bacterial concentration in this trial was $10^{8} \mathrm{CFU} / \mathrm{ml}$. All these field trials were designed as randomized complete blocks with paired-plot design. Each trial included, typically, six experimental treatments (PGPR or chemical inducers) and two controls, a nontreated control and a fungicide control which consisted of spraying with chlorothalonil (Bravo 720), and six replications per treatment. Border rows were planted 2 weeks before the first experi-

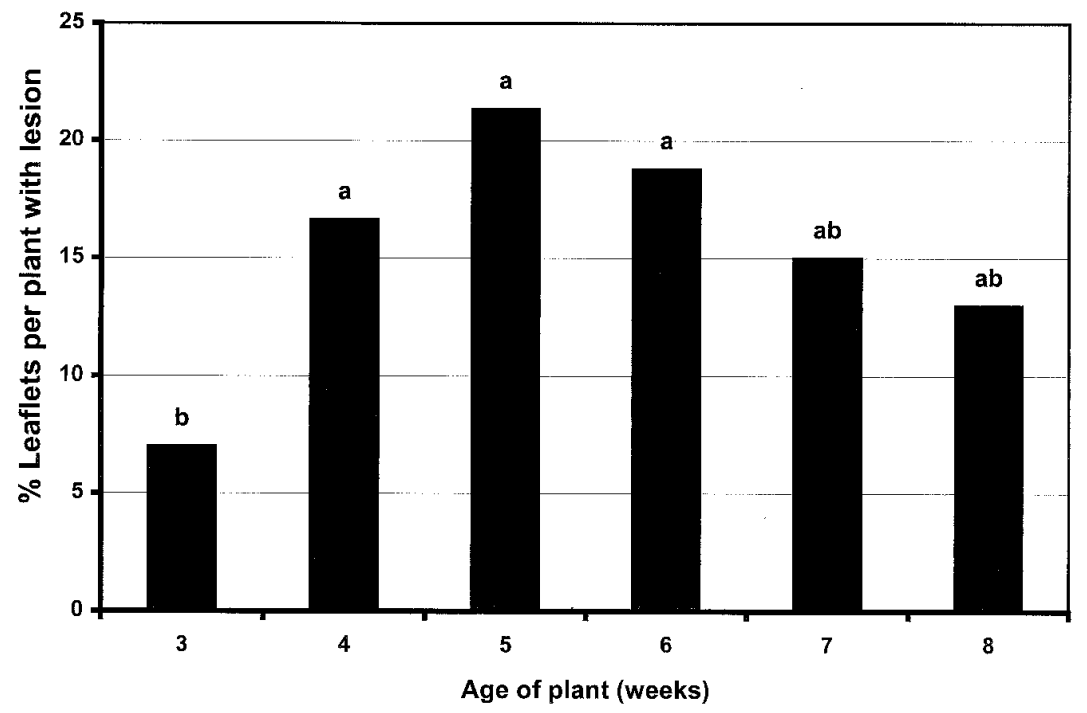

Fig. 1. Effect of plant age on disease severity of late leaf spot of peanut by artificial inoculation with Cercosporidium personatum. Percentage of late leaf spot is calculated from the number of leaflets per plant with lesions. The values are mean from two experiments. Means designated with the same letter are not significantly different at $P=0.05$.

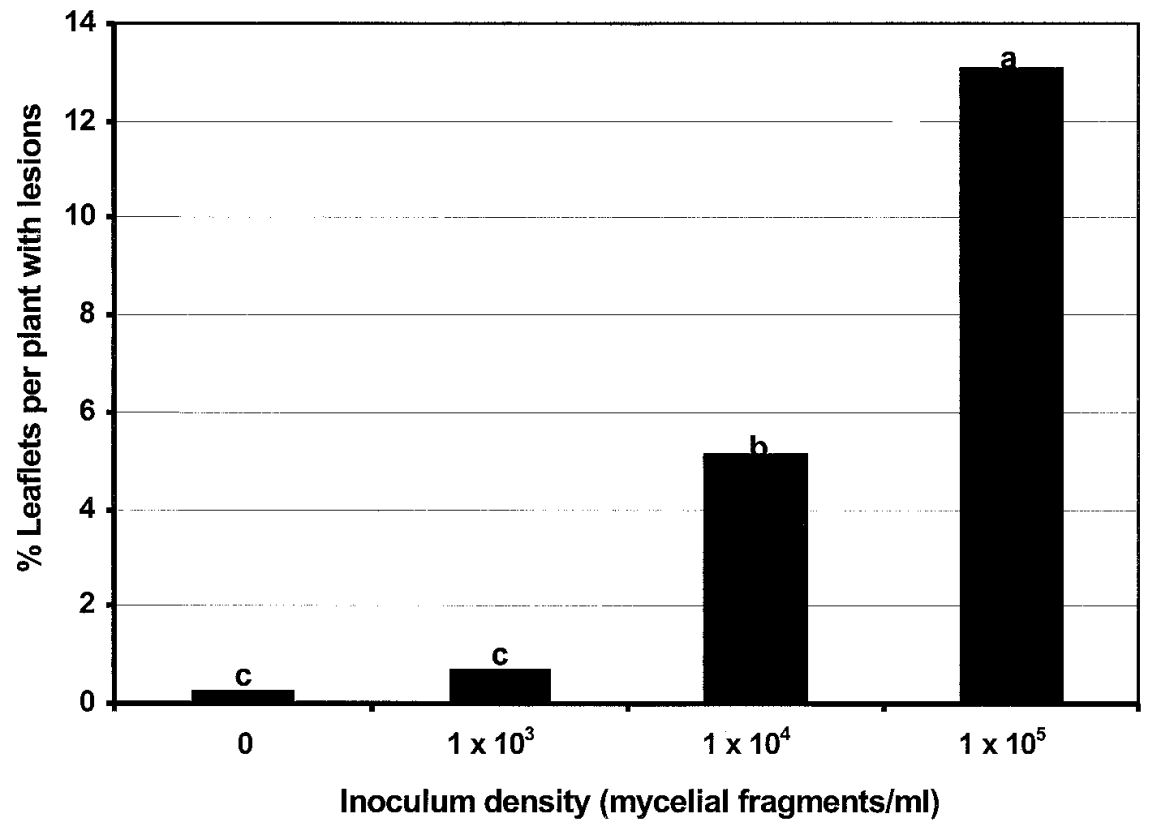

Fig. 2. Effect of inoculum density of Cercosporidium personatum on disease severity of late leaf spot of peanut in the greenhouse. Percentage of leaflets per plant with lesions is a mean from four repeated experiments. 
ments. Bacterial cell suspensions were applied to peanuts planted in an open furrow at $200 \mathrm{ml}$ per $3 \mathrm{~m}$ of row using a $\mathrm{CO}_{2}$ backpack sprayer. Rows were manually closed immediately after application of bacteria with a planet junior planter. No peanut was cultivated at E. V. Smith before this experiment was conducted; therefore, peanut hay carrying the pathogen of late leaf spot was applied over the closed furrows to provide enough inocula of the pathogen to cause late leaf spot on peanut plants in the field. The chemical inducers were applied to peanut foliage at $200 \mathrm{ml}$ per $3 \mathrm{~m}$ of row with a $\mathrm{CO}_{2}$ backpack sprayer 3 weeks after planting. Late leaf spot was rated by counting the number of lesions from a 1-m length of two middle rows in each plot beginning at 3 weeks after planting and continuing weekly for eight weeks, with a final destructive sample at termination of the tests. Number of lesions per plant was then calculated based

Table 2. Results of chemical inducers applied as a foliar spray for control of Cercosporidium leaf spot of peanut in the greenhouse

\begin{tabular}{lcc}
\hline & \multicolumn{2}{c}{ Percent disease compared to a nontreated control ${ }^{\mathbf{a}}$} \\
\cline { 2 - 3 } Inducer, concentration $(\mathbf{m g} / \mathbf{m l})$ & Experiment 1 & Experiment 2 \\
\hline Salicylic acid (SA) & -8 & -2 \\
0.5 & 8 & -2 \\
1.0 & -21 & -6 \\
1.5 & 18 & 5 \\
Sodium salicylate (NaSA) & 7 & -13 \\
0.5 & 6 & -24 \\
1.0 & -18 & -17 \\
1.5 & & \\
2.0 & -7 & -12 \\
DL- $\beta$-amino-n-butyric & & -19 \\
1.0 & $-26^{*}$ & $-34^{*}$ \\
Acid (BABA) & $-68^{*}$ & -6 \\
1.5 & & -7 \\
2.0 & 18 & -3 \\
Isonicotinic acid (INA) & -1 & 27 \\
1.0 & -20 & 38 \\
1.5 & & \\
2.0 & -11 & 18 \\
Benzo [1,2,3] thiadiazole & & \\
0.1 & 9 &
\end{tabular}

a Percent disease was calculated based on the percentage of leaflets per plant with lesions compared to a nontreated control. Each value is the mean of six replications and two plants per replication; * indicates significantly different from the nontreated control according to the least significant difference test at $P=0.05$.

Table 3. Attempts to induce resistance against Cercosporidium leaf spot of peanut with combinations of plant growth-promoting rhizobacteria (PGPR) and DL- $\beta$-amino-n-butyric acid (BABA) in the greenhouse

\begin{tabular}{|c|c|c|c|c|}
\hline \multirow[b]{3}{*}{ PGPR strains } & \multicolumn{4}{|c|}{ Percent disease compared to a nontreated control $^{a}$} \\
\hline & \multicolumn{2}{|c|}{ BABA seed treatment $(\mathrm{mg} / \mathrm{ml})$} & \multicolumn{2}{|c|}{ BABA foliar application $(\mathrm{mg} / \mathrm{ml})$} \\
\hline & 2.5 & 3.0 & 0.5 & $\mathbf{1 . 0}$ \\
\hline $\mathrm{T} 4$ & 2.6 & 28.1 & 15.6 & 18.6 \\
\hline C6 & -5.9 & 9.4 & 33.8 & 24.4 \\
\hline $\mathrm{C} 3$ & -5.3 & 3.9 & 2.2 & 9.0 \\
\hline $\mathrm{C} 1$ & -0.6 & -16.8 & 17.3 & 27.5 \\
\hline
\end{tabular}

a Percent disease was calculated based on the percentage of leaflets per plant with lesions compared to a nontreated control. Each value is the mean of six replications and two plants per replication. based on the 1-to-10 Florida scale, in which $1=$ no disease and $10=$ death or complete defoliation.

Data analysis. Data from greenhouse and field experiments were analyzed separately for each experiment and were submitted to analysis of variance (JMP software; SAS Institute Inc., Cary, NC). The significance of effect of PGPR treatments was determined by the magnitude of the $F$ value $(P=0.05)$. Treatment means were separated by Fisher's protected least significant difference (LSD).

\section{RESULTS}

Optimization of peanut late leaf spot disease assay in the greenhouse. An assay for peanut late leaf spot was optimized. Results from data collected using three different methods for disease measurement were statistically consistent (data not shown); therefore, only a single criterion (i.e., the percentage of leaflets per plant with lesions) was used for data analysis and presentation in further experiments conducted in the greenhouse. Age of peanut plants at the time of challenge and inoculum density significantly affected $(P$ $=0.05$ ) late leaf spot severity (Fig. 1). The maximum level of disease was obtained on 5-week-old plants. Disease severity on 3week-old plants was significantly lower than on plants that were 4,5 , or 6 weeks old. Results with different inoculum densities (Fig. 2) indicated that there was a significant increase in the resulting disease severity with logarithmic increases in inoculum density. Maximum disease severity was noted at $10^{5}$ mycelial fragments $/ \mathrm{ml}$.

Screening of PGPR for potential to elicit systemic protection against late leaf spot in the greenhouse. In the initial tests in which bacteria were applied as seed treatments, none of the eight bacteria significantly reduced disease at either $10^{8}$ or $10^{9} \mathrm{CFU} / \mathrm{ml}$ (data not shown). In subsequent tests in which PGPR were applied as soil drenches and as foliar sprays, 7 of the 19 tested strains (1PN-19, INR-7, T4, SE49, C6, C5, and C1) significantly ( $P=$ 0.05 ) reduced peanut late spot disease severity compared to the nontreated control in one out of two trials in the greenhouse (Table 1). None of the PGPR significantly reduced the disease in both trials.

Tests for elicitation of SAR by $C$. personatum and chemical inducers. The experiment designed to test elicitation of SAR by stem injection of $C$. personatum revealed that there was no systemic protection. The mean disease severity did not differ significantly from that of the nontreated control for any of the steminjection treatments (data not shown).

In the tests of chemical inducers, BABA applied as a foliar spray at $1.5 \mathrm{mg} / \mathrm{ml} \mathrm{sig-}$ nificantly $(P=0.05)$ reduced disease in one of two trials and in both trials when applied at $2.0 \mathrm{mg} / \mathrm{ml}$ (Table 2). No significant disease reduction was observed from 
use of any other chemical inducers at any doses, including Actigard.

In the experiment designed to determine if combinations of BABA and four individual PGPR strains could induce protection against late leaf spot, significant protection, relative to the nontreated control, did not occur with any combination of PGPR and BABA (Table 3).

Field trials. In 1997, there were no significant reductions in AUDPC, which was calculated based on eight weekly disease assessments, with any of the tested PGPR strains at either tested concentration (Table 4). However, significant reductions in numbers of late leaf spot occurred at one sample time (data not shown) with PGPR strains $\mathrm{C} 1$ and $\mathrm{C} 5$; therefore, these were retested in 1998. None of the chemical inducers tested in 1997 provided a significant reduction in AUDPC compared with the nontreated control (Table 5).

In the field trials in 1998, treatment with PGPR strains $\mathrm{C} 1$ and $\mathrm{C} 5$ significantly $(P=$ $0.05)$ reduced the incidence of late leaf spot at 90 days after planting, as did treatment with $\mathrm{BABA}+\mathrm{C} 1$ and both Bravo alone and Bravo with BABA. However, by 105 days after planting, disease reduction with PGPR treatments was not noted, and only the two Bravo treatments significantly reduced disease compared to the nontreated control at that time (Table 6).

\section{DISCUSSION}

Over the past decade, several strains of PGPR, applied to seeds or roots of field crops, have been used as elicitors of ISR, leading to reductions in disease severity in stems or on leaves in cucumber $(30,31)$, carnation (29), bean (1), tomato $(19,24)$, and tobacco $(18,34)$. These reports cover a range of pathogens that cause diverse diseases, including fungal and bacterial wilts, bacterial leaf spots, and fungal leaf diseases. To date, there are no publications reporting attempts to use PGPR strains as elicitors of ISR in peanut. The results reported here indicate that PGPR strains that previously elicited ISR on tobacco, tomato, or cucumber $(15,16,19,22-24,30-34)$ did not repeatedly induce significant reductions in severity of late leaf spot in peanut. In some experiments in both the greenhouse and field, individual treatments of some PGPR strains did result in significant protection; however, this was not reproducible.

One possible explanation for the lack of significant reproducible reduction in late leaf spot disease with PGPR is that peanut is not an inducible plant, at least not systemically inducible. Supporting this conclusion are our results indicating lack of significant disease protection following stem injection with the pathogen $C$. personatum or with chemical elicitors, including salicylic acid, sodium salicylate, isonicotinic acid, and Actigard, which are reported to elicit SAR on a large number of crops (27). During the product development phase of Actigard, extensive field trials were conducted with peanut and other crops, and reproducible disease re- ductions were not observed with peanut as they were on many other crops (A. Tally, personal communication). It was also reported that use of Actigard on peanut did

Table 4. Summary of field trials in 1997 with plant growth-promoting rhizobacteria (PGPR) tested for possible elicitation of induced systemic resistance against late leaf spot of peanut

\begin{tabular}{|c|c|c|c|}
\hline PGPR treatment & Bacterial concentration $(\mathrm{CFU} / \mathrm{ml})$ & AUDPC $^{\mathbf{a}}$ & Percent difference $^{b}$ \\
\hline \multirow[t]{2}{*}{$3 P 1-8$} & $1.0 \times 10^{9}$ & 13.23 & 10.8 \\
\hline & $1.0 \times 10^{7}$ & 10.82 & -9.4 \\
\hline \multirow[t]{2}{*}{$3 P 1-14$} & $1.0 \times 10^{9}$ & 12.78 & 7.1 \\
\hline & $1.0 \times 10^{7}$ & 13.30 & 11.4 \\
\hline \multirow[t]{2}{*}{ 1PC-11 } & $1.0 \times 10^{9}$ & 14.03 & -20.6 \\
\hline & $1.0 \times 10^{7}$ & 14.89 & -15.8 \\
\hline \multirow[t]{2}{*}{ 1PL-2 } & $1.0 \times 10^{9}$ & 16.87 & -15.1 \\
\hline & $1.0 \times 10^{7}$ & 15.16 & -23.7 \\
\hline \multirow[t]{2}{*}{$1 \mathrm{PN}-19$} & $1.0 \times 10^{9}$ & 19.95 & 0.4 \\
\hline & $1.0 \times 10^{7}$ & 21.60 & -8.7 \\
\hline \multirow[t]{2}{*}{ INR-7 } & $1.0 \times 10^{9}$ & 17.26 & -13.2 \\
\hline & $1.0 \times 10^{7}$ & 21.95 & 10.4 \\
\hline \multirow[t]{2}{*}{ IN937a } & $1.0 \times 10^{9}$ & 15.60 & -11.8 \\
\hline & $1.0 \times 10^{7}$ & 24.48 & 39.6 \\
\hline \multirow[t]{2}{*}{ IN937b } & $1.0 \times 10^{9}$ & 24.49 & 38.5 \\
\hline & $1.0 \times 10^{7}$ & 16.75 & -5.3 \\
\hline \multirow[t]{2}{*}{$\mathrm{T} 4$} & $1.0 \times 10^{9}$ & 13.06 & 9.4 \\
\hline & $1.0 \times 10^{7}$ & 13.51 & 13.1 \\
\hline \multirow[t]{2}{*}{ SE34 } & $1.0 \times 10^{9}$ & 20.40 & 10.6 \\
\hline & $1.0 \times 10^{7}$ & 19.18 & 4.1 \\
\hline \multirow[t]{2}{*}{ SE49 } & $1.0 \times 10^{9}$ & 20.37 & 10.5 \\
\hline & $1.0 \times 10^{7}$ & 16.77 & -9.1 \\
\hline \multirow[t]{2}{*}{ SE56 } & $1.0 \times 10^{9}$ & 18.24 & -1.1 \\
\hline & $1.0 \times 10^{7}$ & 19.60 & 6.7 \\
\hline \multirow[t]{2}{*}{ SE76 } & $1.0 \times 10^{9}$ & 12.71 & 12.7 \\
\hline & $1.0 \times 10^{7}$ & 8.65 & -8.7 \\
\hline \multirow[t]{2}{*}{$\mathrm{C} 10$} & $1.0 \times 10^{9}$ & 10.85 & -10.9 \\
\hline & $1.0 \times 10^{7}$ & 12.50 & -12.5 \\
\hline \multirow[t]{2}{*}{ C9 } & $1.0 \times 10^{9}$ & 10.50 & -10.5 \\
\hline & $1.0 \times 10^{7}$ & 12.25 & -12.3 \\
\hline \multirow[t]{2}{*}{ C6 } & $1.0 \times 10^{9}$ & 27.88 & 71.2 \\
\hline & $1.0 \times 10^{7}$ & 23.80 & 46.6 \\
\hline \multirow[t]{2}{*}{ C5 } & $1.0 \times 10^{9}$ & 27.46 & 69.1 \\
\hline & $1.0 \times 10^{7}$ & 20.23 & 24.6 \\
\hline \multirow[t]{2}{*}{$\mathrm{C} 3$} & $1.0 \times 10^{9}$ & 17.00 & 4.7 \\
\hline & $1.0 \times 10^{7}$ & 19.13 & 17.8 \\
\hline \multirow[t]{2}{*}{$\mathrm{C} 1$} & $1.0 \times 10^{9}$ & 20.91 & 28.8 \\
\hline & $1.0 \times 10^{7}$ & 18.62 & 14.7 \\
\hline
\end{tabular}

a Area under the disease progress curve (AUDPC) for number of lesions per plant calculated for data collected at the period of time from 21 to 70 days after planting. Values are means of six replications. Data are summarized from several experiments, and the appropriate nontreated control in each experiment was used to calculate percent difference of AUDPC.

${ }^{\mathrm{b}}$ Compared with a nontreated control.

Table 5. Summary of field trials in 1997 with chemical inducers tested for possible elicitation of induced systemic resistance against late leaf spot of peanut

\begin{tabular}{|c|c|c|}
\hline Chemical inducers, concentration $(\mathrm{mg} / \mathrm{ml})$ & AUDPC & $\begin{array}{c}\text { Percent } \\
\text { difference }^{b}\end{array}$ \\
\hline \multicolumn{3}{|l|}{ Salicylic acid (SA) } \\
\hline 0.5 & 6.5 & 0 \\
\hline 1.0 & 7.1 & 8.5 \\
\hline \multicolumn{3}{|l|}{ Sodium salicylate (NaSA) } \\
\hline 0.5 & 10.2 & 21.8 \\
\hline 1.0 & 10.9 & 35.4 \\
\hline \multicolumn{3}{|l|}{ DL- $\beta$-amino-n-butyric acid (BABA) } \\
\hline 1.0 & 7.5 & 15.4 \\
\hline 2.0 & 6.6 & 1.5 \\
\hline \multicolumn{3}{|l|}{ Isonicotinic acid (INA) } \\
\hline 1.5 & 8.5 & 5.6 \\
\hline 2.0 & 12.3 & 52.2 \\
\hline \multicolumn{3}{|c|}{ Benzo $[1,2,3]$ thiadiazole-7-carbothioic acid S-methyl ester (Actigard) } \\
\hline 0.03 & 8.8 & 35.4 \\
\hline
\end{tabular}

a Area under the disease progress curve (AUDPC) for number of lesions per plant was calculated for data collected at the period of time from 21 to 70 days after planting. Values are means of six replications.

b AUDPC compared with a nontreated control. 
Table 6. Summary of field trials in 1998 with plant growth-promoting rhizobacteria (PGPR) and DL$\beta$-amino-n-butyric acid (BABA) as potential elicitors of induced resistance against late leaf spot of peanut

\begin{tabular}{lcc}
\hline & \multicolumn{2}{c}{ Late leaf spot incidence $^{\mathbf{a}}$} \\
\cline { 2 - 3 } Treatment & $\mathbf{9 0}$ days after planting & $\mathbf{1 0 5}^{\text {days after planting }}$ \\
\hline C1 & $3.1^{*}$ & 5.5 \\
C3 & 4.7 & 5.2 \\
C5 & $3.2^{*}$ & 5.1 \\
T4 & 4.1 & 5.2 \\
C1 + BABA & $2.1^{*}$ & 5.4 \\
C3 + BABA & 4.1 & 5.3 \\
C5 + BABA & 4.3 & 5.4 \\
T4 + BABA & 4.3 & 4.7 \\
Bravo + BABA & $1.9^{*}$ & $3.6^{*}$ \\
Bravo alone & $2.9^{*}$ & $3.4^{*}$ \\
BABA alone & 3.6 & 4.7 \\
Nontreated control & 4.6 & 5.1 \\
\hline
\end{tabular}

a The incidence of late leaf spot is based on the 1-to-10 Florida scale, in which $1=$ no disease and 10 $=$ dead or complete defoliation of the peanut plants. Values are mean of six replications; $*$ indicates significantly different from a nontreated control according to the least significant difference test at $P=0.05$.

not result in control of Sclerotinia blight (13). It should be noted, however, that it is unknown if Actigard and other chemical elicitors cause increases in pathogenesisrelated $(\mathrm{PR})$ proteins in peanut associated with SAR, despite the lack of consistent disease protection.

The only chemical elicitor which significantly reduced late leaf spot disease in our work was BABA, which occurred only at a high concentration in the greenhouse. BABA is reported to be an elicitor of local, but not systemic acquired resistance, leading to protection of tomato plants against Phytophthora infestans (6), tobacco against Peronospora tabacina (5), and pea against Aphanomyces euteiches (20). Collectively, our results suggest that peanut is not systemically inducible in the same way as are other crops by PGPR and chemical inducers.

\section{LITERATURE CITED}

1. Alström, S. 1991. Induction of disease resistance in common bean susceptible to halo blight bacterial pathogen after seed bacterization with rhizosphere pseudomonads. J. Gen. Appl. Microbiol. 37:495-501.

2. Backman, P. A., Rodriguez-Kabana, R., and Williams, J. C. 1975. The effect of peanut leaf spot fungicides in the nontarget pathogen Sclerotium rolfsii. Phytopathology 65:773-776.

3. Campbell, W. V. 1978. Effect of pesticide interactions on the two spotted spider mite on peanuts. Peanut Sci. 5:83-86.

4. Clark, E. M., Backman, P. A., and RodriguezKabana, R. 1974. Cercospora and Cercosporidium tolerance to related fungicides in Alabama peanut fields. Phytopathology 64:1476-1477.

5. Cohen, Y. 1994. 3-Aminobutyric acid induced systemic resistance against Peronospora tabacina. Physiol. Mol. Plant Pathol. 44:273-288.

6. Cohen, Y. 1994. Local and systemic control of Phytophthora infestans in tomato plants by DL-3-amino-n-butanoic acids. Phytopathology 84:55-59.

7. El-Gholl, N. E., Alfieri, S. A., Jr., Ridings, W. H., and Schoulties, C. L. 1982. Growth and sporulation in vitro of Cercospora apii, Cercospora arachidicola, Cercospora kikuchii, and other species of Cercospora. Can. J. Bot. 60:862-868.

8. Gorbet, D. W., Norden, A. J., Shokes, F. M., and Knauft, D. A. 1986. Southern runner: a new resistant-resistant peanut variety. Circ. S324, University of Florida, Gainesville.

9. Jackson, C. R., and Bell, D. K. 1969. Diseases of peanut (groundnut) caused by fungi. Univ. Ga. Coll. Agric. Exp. Stn. Res. Bull. 56:1-5.

10. Kokalis-Burelle, N., Backman, P. A., Rodríguez-Kábana, R., and Ploper, L. D. 1992. Potential for biological control of early leaf spot of peanut using Bacillus cereus and chitin as foliar amendments. Bio. Control 2:321-328.

11. Kokalis-Burelle, N., Porter, D. M., RodríguezKábana, R., Smith, D. H., and Subrahmanyam, P., eds. 1997. Compendium of Peanut Diseases. American Phytopathology Society, St. Paul, MN.

12. Kvien, C. S., Csinos, A. S., Ross, L. E., Conkerton, E. J., and Styer, C. 1987. Diniconazole's effect on peanut (Arachis hypogaea L.) growth and development. J. Plant Growth Regul. 6:233-244.

13. Lemay, A. V., and Bailey, J. E. 1998. The management of Sclerotinia Blight (Sclerotinia minor) on peanut with the systemic inducer Actigard, the fungicide fluazinam, and resistant genotypes. (Abstr.) Phytopathology 88:S53.

14. Littrell, R. H. 1974. Tolerance in Cercospora arachidicola to benomyl and related fungicides. Phytopathology 64:1377-1378.

15. Liu, L. Kloepper, J. W., and Tuzun, S. 1995. Induction of systemic resistance in cucumber against Fusarium wilt by plant growthpromoting rhizobacteria. Phytopathology 85:695-698.

16. Liu, L. Kloepper, J. W., and Tuzun, S. 1995. Induction of systemic resistance in cucumber against bacterial angular leaf spot by plant growth-promoting rhizobacteria. Phytopathology 85:843-847.

17. Liu, T. M. E., and Chen, C. Y. 1980. Studies on Cercospora leaf spots of peanut. I. The effect of light on sporulation of Cercospora arachidicola and Cercosporidium personatum. Mem. Coll. Agric. Natl. Taiwan Univ. 20:13-15.

18. Maurhofer, M., Hase, C., Meuwly, P., Metraux, J. P., and Défago, G. 1994. Induction of systemic resistance of tobacco to tobacco necrosis virus by the root-colonizing Pseudomonas fluorescens strain CHAO: Influence of the gacA gene and of pyoverdine production. Phytopathology 84:139-146.

19. Murphy, J. F., Zehnder, G. W., Schuster, D. J., Sikora, E. J., Polston, J. E., and Kloepper, J. W. 2000. Plant growth-promoting rhizobacterial mediated protection in tomato against To- mato mottle virus. Plant Dis. 84:779-784.

20. Papavizas, F. G. 1964. Greenhouse control of Aphanomyces root rot of peas with aminobutyric acid and methylaspartic acid. Plant Dis. Rep. 48:537-541

21. Porter, D. M. 1980. Increased severity of Sclerotinia blight in peanuts treated with captafol and chlorothalonil. Plant Dis. 64:394-395.

22. Raupach, G. S., and Kloepper, J. W. 1998. Mixtures of plant growth-promoting rhizobacteria enhance biological control of multiple cucumber pathogens. Phytopathology 88:1158-1164.

23. Raupach, G. S., and Kloepper, J. W. 2000. Biocontrol of cucumber diseases in the field by plant growth-promoting rhizobacteria with and without methyl bromide fumigation. Plant Dis. 84:1073-1075.

24. Raupach, G. S., Liu, L., Murphy, J. F., Tuzun, S., and Kloepper, J. W. 1996. Induced systemic resistance in cucumber and tomato against cucumber mosaic virus using plant growth-promoting rhizobacteria (PGPR). Plant Dis. 80:891-894.

25. Shokes, F. M., and Smith, D. H. 1990. Integrated systems for management of peanut diseases. Handbook of pest management in agriculture, Volume III. D. Pimentel, ed. CRC Press, Boca Raton, FL.

26. Smith, D. H., Pauer, G. D. C., and Shokes, F M. 1992. Plant diseases of international importance. Diseases of Vegetables and oil seed crops, vol. II. H. S. Chaube, J. Kumar, A. N. Mukhopadhyay, and U. S. Singh, eds. Prentice Hall, Englewood Cliffs, NJ.

27. Tally, A., Oostendorp, M, Lawton, K., Staub, T., and Bassi, B. 1999. Commercial development of elicitors of induced resistance to pathogens. Pages 357-369 in: Induced Plant Defenses Against Pathogens and Herbivores, Biochemistry, Ecology, and Agriculture. A. A. Agrawal, S. Tuzun, and E. Bent, eds. APS Press, St. Paul, MN.

28. van Loon, L. C., Bakker, P. A. H. M., and Pieterse, C. M. J. 1998. Systemic resistance induced by rhizosphere bacteria. Annu. Rev. Phytopathol. 36:453-483.

29. van Peer, R., Niemann, G. J., and Schippers, B. 1991. Induced resistance and phytoalexin accumulation in biological control of Fusarium wilt of carnation by Pseudomonas $s p$. strain WCS417r. Phytopathology 81:728-734.

30. Wei, G., Kloepper, J. W., and Tuzun, S. 1991. Induction of systemic resistance of cucumber to Colletotrichum orbiculare by select strains of plant growth-promoting rhizobacteria. Phytopathology 81:1508-1512.

31. Wei, G., Kloepper, J. W., and Tuzun, S. 1996. Induced systemic resistance to cucumber diseases and increase plant growth by plant growth-promoting rhizobacteria under field conditions. Phytopathology 86:221-224.

32. Zehnder, G. W., Yao, C., Murphy, J. F., Sikora, E. R., and Kloepper, J. W. 2000. Induction of resistance in tomato against cucumber mosaic cucumovirus by plant growthpromoting rhizobacteria. Bio. Control 45:127137.

33. Zehnder, G. W., Yao, C., Murphy, J. F., Sikora, E. R., Kloepper, J. W., Schuster, D. J., and Polston, J. E. 1999 Microbe-induced resistance against pathogens and herbivores: Evidence of effectiveness in agriculture. Pages 335-355 369 in: Induced Plant Defenses Against Pathogens and Herbivores, Biochemistry, Ecology, and Agriculture. A. A. Agrawal, S. Tuzun, and E. Bent, eds. APS Press, St. Paul, MN.

34. Zhang, S., Reddy, M. S., Ryu, C. M., and Kloepper, J. W. 1999. Relationship between in vitro and in vivo testing of PGPR for induced systemic resistance against tobacco blue mold. (Abstr.) Phytopathology 89:S89. 